\title{
Komodifikasi Pesan Dakwah Pada Iklan Pertamina Versi Tabungan Terbaik di Televisi
}

\author{
Miftahul Huda \\ Magister Komunikasi dan Penyiaran Islam \\ Universitas Islam Negeri Sunan Kalijaga Yogyakarta \\ Miftahulhudadt91@gmail.com
}

\begin{abstract}
In this study, The researcher discussed about the commodification of da'wah messages on pertamina ads, the best savings version. This study included a type of qualitative research using $S$ Jager and F Maier's critical discourse analysis methods by making a synopsis, determining the main characters, discursive practices, non-discursive practices, object materialization, and theorizing of advertising themes. Based on the results of the analysis, it was found that there were signs that identified the practice of commodification of da'wah messages on the best savings version of pertamina ads in the form of images, conversations, and texts in the description of the ad stories. The message of commodified da'wah becomes a narrative that charity will be a shelter for humans when in the hereafter. The missionary message was conveyed in order to increase knowledge, change attitudes and mindset of the community and convey corporate messages so that people are economical in using fuel and not too consumptive in buying motorcycles. The researcher concluded that da'wah messages which are noble religious messages in order to change buman beings for the better and get happiness in the world and the hereafter can be packaged and utilized as a matter for transforming values into exchange values that are image-building for corporate interests.
\end{abstract}

Keywords: Commodification, Religious Message, Television Advertising.

\begin{abstract}
Abstrak
Dalam penelitian ini membahas tentang komodifikasi pesan dakwah pada iklan pertamina versi tabungan terbaik. Penelitian ini termasuk jenis penelitian kualitatif dengan menggunakan metode analisis wacana kritis $\mathrm{S}$ Jager dan F Maier dengan membuat sinopsis, menentukan tokoh utama, praktik diskursif, praktik non diskursif, materialisasi objek, dan teoretisasi tema iklan. Berdasarkan hasil analisis, ditemukan adanya tanda yang mengidentifikasi terjadinya praktik komodifikasi pesan dakwah pada iklan pertamina versi tabungan terbaik berupa gambar, percakapan, dan teks
\end{abstract}

Jurnal Dakwah dan Komunikasi

IAIN Curup-Bengkulu | E-ISSN: 2548-3366; P-ISSN: 2548-3293 
dalam penggambaran cerita iklan tersebut. Pesan dakwah dikomodifikasi menjadi narasi bahwa amal sedekah akan menjadi naungan manusia ketika di akhirat. Pesan dakwah tersebut disampaikan dalam rangka untuk meningkatkan pengetahuan, mengubah sikap dan pola pikir masyarakat serta menyampaikanpesan korporasi agar manusia hemat dalam menggunakan bahan bakar minyak serta tidak terlalu konsumtif dalam membeli motor. Peneliti menyimpulkan bahwa pesan dakwah yang merupakan pesan agama yang mulia dalam rangka mengubah manusia menjadi lebih baik dan mendapatkan kebahagiaan di dunia dan akhirat dapat dikemas dan dimanfaatkan sebagai suatu hal untuk transformasi nilai menjadi nilai tukar yang bersifat pembangunan citra demi kepentingan korporasi.

Kata Kunci: Komodifikasi, Pesan Agama, Iklan Televisi.

\section{Pendahuluan}

Di era keterbukaan saat ini, produk produk iklan mudah dijumpai seperti di jalan raya, tempat umum, papan informasi, media massa, sosial media dan lain sebagainya. Iklan memiliki fungsi utama untuk menyampaikan informasi suatu produk kepada khalayak. ${ }^{1}$ Iklan sering menjadi pengisi dalam ruang media, baik cetak maupun elektronik. Salah satu contoh media yang menjadi sarana iklan adalah televisi.

Televisi merupakan media iklan yang paling berpengaruh dan kuat dalam menjangkau kalangan konsumen yang luas, sehingga iklan televisi dapat menjadi media efektif untuk mendemonstrasikan atribut produk dengan jelas secara persuasif. Selain itu, iklan televisi juga dapat menggambarkan pengguna dan pencitraan penggunaan, kepribadian merek, dan hal yang bersifat abstrak secara dramatis. ${ }^{2}$ Menurut Gerbner, televisi merupakan agama masyarakat industri dimana tayangan dan acaranya akan selalu didengar dan disaksikan oleh semua orang lintas agama. Iklan dalam televisi merupakn sebuah tayangan yang diibaratkan seperti khtubahnya agama yang tidak hanya memasarkan produk, tetapi juga memasarkan nilai, sikap, dan gaya hidup sehingga menjadikan televisi sebagai media komunikasi dan infornmasi yang sangat berpengaruh di era modern saat ini. ${ }^{3}$

Iklan melalui televisi memiliki kelebihan dalam menyampaikan pesan kepada khalayak karena memadukan kata-kata, suara dan gambar bergerak secara bersama sehingga lebih menarik, mudah diterima, dan mengena di hati khalayak. Pada umumnya iklan berisi sebuah pencapaian atau pemenuhan harapan yang biasanya dikemas dengan mengikutsertakan kelas sosial dari golongan tertentu seperti artis, politisi, tokoh agama, dan lain-lain.

\footnotetext{
${ }^{1}$ Alo liliweri, Dasar-dasar Komunikasi Periklanan, (Bandung: PT. Citra Aditya Bakti, 1992), 17.

${ }^{2}$ Keller, dkk., Manajemen Pemasaran, ed. 13, jil. 2, (Jakarta: Erlangga, 2009), 205-206.

${ }^{3}$ Samsul Munir Amin, Imu Dakwah, (Jakarta: Amzah, 2009), hm. 115.
} 
Televisi saat ini memiliki peran yang sangat penting terhadap realitas sosial yang sedang berkembang. Televisi tidak hanya menjadi sarana untuk menyalurkan informasi tetapi juga untuk menyusun agenda dan memberitahukan terkait hal-hal yang penting bagi manusia. ${ }^{4}$

Dalam perkembanganya, iklan televisi tidak hanya menjadi sarana pemasaran dan tempat membangun citra dari perusahaaan atau korporasi dengan menampilkan produknya tetapi melalui cara-cara yang lebih halus dalam pengemasannya seperti iklan pertamina.

Pertamina merupakan badan usaha milik negara yang mengelola minyak bumi dan gas. Pertamina memiliki kegiatan pokok dalam eksplorasi dan produksi minyak, gas, dan panas bumi. Kegiatan tersebut dalam rangka untuk menemukan cadangan baru dan menjamin kelangsungan produksi. Kegiatan yang lain adalah untuk memenuhi kebutuhan produk bahan bakar minyak (BBM) dalam negeri serta menjamin ketersediaan produknya.

Pertamina merupakan salah satu perusahaan atau korporasi yang sering menjadikan televisi sebagai media iklannya. Pertamina juga sering menjadikan momen-momen istimewa, baik yang berkaitan dengan hari besar nasional maupun hari besar keagamaan menjadi momentum untuk beriklan.

Pada bulan ramadhan, di Indonesia bentuk iklan yang ditayangkan di media televisi memiliki corak dan nuansa yang berbeda. Perbedaan tersebut tidak dapat terlepas dari kondisi mayoritas penduduk Indonesia yang menjadi sasaran iklan sedang menjalani ibadah puasa karena beragama Islam. Dengan kondisi tersebut, kreator iklan media televisi biasanya mengemas iklan dengan konsep dan nuansa religius.

Pada bulan puasa juga sering dimanfaatkan oleh kreator iklan sebagai strategi dengan mengkodifikasi hal-hal tertentu yang tidak hanya menampakkan produk yang ingin dipasarkan saja. Komodifikasi menjadi sebuah transformasi dari hubungan yang awalnya terbebas dari hal-hal yang bersifat diperdagangkan menjadi hubungan yang bersifat komersial. Seperti dalam iklan ini, pertamina mengangkat tema tabungan terbaik, dimana digambarkan seorang bapak memberikan pesan dakwah kepada anaknya tentang pentingnya bersedekah. Dakwah tersebut dilakukan melalui keteladanan dan mavizah hasanah.

Dari paparan di atas, penelitian ini bermaksud untuk mengetahui bagaimana gambaran terkait komodifikasi pesan dakwah pada iklan pertamina versi tabungan terbaik yang diproduksi dan ditayangkan melalui media televisi pada ramadhan tahun 2018.

\section{Kerangka Teori dan Konsep}

1. Komodifikasi

Komodifikasi merupakan proses transformasi nilai guna menjadi nilai tukar. Sebuah barang dinilai tidak berdasarkan pada kemampuanya dalam memenuhi kebutuhan seseorang tetapi dinilai dengan apa yang

${ }^{4}$ Syaiful Halim, Postkomodifikasi Media: Analisis Media Televisi dengan Teori Kritis dan Cultural Studies, (Yogyakarta: Jalasutra, 2013), 68. 
dibawa ke ranah pasar. ${ }^{5}$ Dalam penelitian ini, yang dimaksud dengan komodifikasi adalah transformasi nilai guna pesan dakwah menjadi nilai tukar yang disesuaikan dengan kebutuhan manusia dan sebagai media untuk membangun citra, ideologi, dan menyampaikan misi dari korporasi.

2. Pesan Dakwah

Pesan secara bahasa berarti nasihat, permintaan, dan amanat yang dilakukan atau disampaikan orang lain. ${ }^{\top}$ Pengertian dakwah jika ditilik dari segi bahasa (etimologi), berarti memanggil, mengundang, mengajak, menyeru, mendorong ataupun memohon. ${ }^{7}$ Arti dakwah menurut Quraish Shihab adalah seruan atau ajakan kepada keinsyafan atau usaha mengubah situasi menjadi lebih baik. Dakwah juga dapat diartikan sebagai suatu proses untuk mengubah situasi dan kondisi menjadi lebih baik sesuai dengan ajaran Islam. ${ }^{8}$

Adapun pengertian dakwah menurut Jamaluddin Kafie adalah adalah suatu sistem kegiatan dari seseorang, atau kelompok yang dimanifestasikan dalam bentuk seruan, ajakan, dan do'a, yang disampaikan dengan menggunakan metode, sistem, dan tehnik tertentu, agar mampu menyentuh kalbu dan fitrah seseorang, keluarga, kelompok, massa, dan masyarakat supaya dapat mempengaruhi tingkah lakunya untuk mencapai suatu tujuan tertentu. ${ }^{?}$

Sedangkan pengertian dakwah menurut Toha Yahya Omar adalah mengajak manusia dengan cara bijaksana kepada jalan yang benar sesuai dengan perintah Tuhan, untuk keselamatan dan kebahagiaan mereka di dunia dan akhirat. ${ }^{10}$

Dalam dakwah, yang menjadi prioritas utama adalah keluarga terlebih dahulu. Hal tersebut pernah dicontohkan oleh Nabi Muhammad ketika sebelum berdakwah secara terang-terangan, beliau terlebih dahulu berdakwah kepada keluarga dan sahabat terdekatnya.

Materi dakwah adalah pesan dakwah atau ajaran islam yang berada di dalam al quran maupun yang al hadits atau segala yang diteladankan oleh rasulullah. ${ }^{11}$ Pada dasarnya pesan dakwah tergantung pada tujuan yang ingin disampaikan oleh subjek dakwah atau dai kepada objek dakwah atau mad'u. Namun secara umum materi dakwah berkaitan dengan masalah keimanan, kesilaman, dan budi pekerti atau akhlaqul karimah. ${ }^{12}$

\section{Teori Komunikasi Massa.}

${ }^{5}$ Filosa Gita Sukmono, dkk, Ekonomi Politik Media: Sebuah Kajian Kritis, (Yogyakarta: Lingkar Media, 2013), 114.

${ }^{6}$ WJS. Purwodarminto, Kamus Umum Bahasa Indonesia, Jakarta: PN. Balai Pustaka, 1984), 677.

${ }^{7}$ Fathul Bahri an-Nabiri, Meniti Jalan Dakwab: Bekal Perjuangan Para Da`, Jakarta : Amzah, 2008), 17.

${ }^{8}$ Wardi Bakhtiar, Metode Penelitian Ilmu Dakwah, (Jakarta: Logos, 1981), 31.

${ }^{9}$ Toha Yahya Omar, Ilmu Dakwah, (Jakarta: Wijaya, 1984), hlm. 1.

${ }^{10}$ Samsul Munir Amir, Op. Cit., hlm. 3.

${ }^{11}$ Hafi Anshari, Pemahaman dan Pengamalan Dakwah, (Surabay: Al Ikhlas, 1993), 140.

${ }^{12}$ Samsul Munir Amir, Op. Cit., 89. 
Komunikasi massa adalah komunikasi yang dilakukan melalui media massa. Komunikasi massa merupakan suatu proses dimana para komunikator menggunakan media untuk menyebarkan pesan-pesan secara luas, dan secara terus menerus menciptakan makna-makna yang diharapkan dapat mempengaruhi khalayak yang besar dan berbeda-beda melalui berbagai cara.

Komunikasi massa memiliki tujuh ciri khas atau karakteristik yaitu, ditujukan kepada khalayak luas, bentuk komunikasi bersifat umum, pola penyampaian pesan secara tepat, penyampaian pesan berjalan satu arah, kegiatan komunikasi massa dilakukan secara terencana, terjadwal, dan terorganisir. Penyampaian pesan dilakukan secara berkala, dan isi pesan mencakup berbagai bidang kehidupan manusia.

a. Media Televisi

Televisi berasal dari kata tele dan vision. Tele berarti jauh dan vision berarti tampak. Jadi televisi berarti tampak atau dapat melihat dari jarak jauh.Televisi dipandang sebagai media yang paling efektif dan efisien untuk menyampaikan pesan atau iklan. Keunggulan televisi dalam menyampaikan iklan adalah kemampuannya menjangkau khalayak sasaran yang sangat luas. Saat ini, hampir setiap rumah memiliki televisi, bahkan dalam satu rumah ada yang memiliki lebih dari satu televisi. Kelebihan yang lain adalah kemampuan menimbulkan dampak yang kuat terhadap konsumen serta kemampuan untuk mempengaruhi persepsi khalayak sasaran, karena mayoritas masyarakat meluangkan waktunya di muka televisi. ${ }^{13}$

b. Komunikasi massa media televisi

Komunikasi massa media televisi adalah proses komunikasi yang dilakukan antara komunikator dengan komunikan melalui sebuah sarana televisi. Komunikasi massa media televisi bersifat periodik. Dalam komunikasi massa media televisi lemabaga penyelenggara melibatkan banyak orang sesuai dengan tugas pokok dan fungsinya masing-masing . setiap pesan yang disampaikan dalam media televisi tentunya memiliki tujuan untuk mempengaruhi khalayak, baik secara langsung maupun tidak langsung.Selain itu, dalam komunikasi massa media televisi juga memiliki tujuan untuk menghibur, mendidik, bahan informasi, dan kontrol sosial kepada khalayak. Isi pesan dalam komunikasi massa media televisi biasanya berasal dari fenomena atau isu yang terjadi di masyarakat atau dapat berupa propaganda ideologi tertentu ${ }^{14}$

c. Iklan Televisi

Iklan secara sederhana dapat diartikan sebagai pesan yang menawarkan suatu produk atau komunikasi publik yang bersifat persuasif. Iklan ditujukan kepada masyarakat melalui suatu media dengan

${ }^{13}$ Adi Badjuri, Jurnalistik Televisi, (Yogyakarta : Graha Ilmu, 2010), 6.

${ }^{14}$ Wawan Kuswandi, Komunikasi Massa, Sebuah Analisis Media Televisi, Jakarta : PT Rineka Cipta, 1996), 16-18. 
membayar ruang yang dipakai oleh perusahaan, lembaga non komersial, dan pribadi yang memiliki kepentingan.

Iklan dalam media televisi termasuk kategori iklan above the line atau media lini atas, artinya iklan yang menggunakan media yang bersifat massa, memiliki penonoton dengan jumlah besar, serta antara satu dengan yang lainya tidak saling mengenal. Selain itu iklan dalam media televisi juga mengandung unsur suara, gambar, dan gerak. ${ }^{15}$

Iklan Televisi terdiri dari dari iklan komersial dan iklan layanan masyarakat. Iklan komersial merupakan iklan yang bertujuan untuk mendapatkan keuntungan secara ekonomi. Iklan komersial terbagi dalam tiga bentuk, yaitu iklan untuk konsumen, iklan untuk bisnis, dan iklan untuk profesional.

Adapun iklan layanan masyarakat adalah iklan yang digunakan untuk menyampaikan informasi, membujuk dan mendidik masyarakat yang tujuan akhirnya tidak menekankan pada aspek keuntungan secara ekonomis tetapi untuk keuntungan sosial yang berbentuk adanya peningkatan pengetahuan, kesadaran sikap, perubahan perilaku, dan pembangunan citra baik. ${ }^{16}$

Tujuan iklan adalah untuk mendorong masyarakat agar membeli produk yang diiklankan. Agar tujuan tersebut dapat berjalan dengan lancar dan tidak terlihat kasar atau memaksa, iklan menampilkan berbagai macam strategi dengan memainkan psikologi seseorang, membujuk, memanfaatkan budaya, menampilkan diri sesering mungkin di hadapan publik, dan kemudian mengajarkan masyarakat untuk melihat, memilih, dan mengkonsumsi (Supriadi, 2013).

\section{Metode Penelitian}

Dalam penelitian ini permasalahan yang diteliti adalah terkait komodifikasi pesan dakwah pada iklan pertamina versi tabungan terbaik. Penelitian ini termasuk jenis penelitian kualitatif. Peneliian kualitatif merupakan sebuah proses penyelidikan untuk memahami masalah sosial atau masalah manusia berdasarkan pada penciptaan gambar holistik yang dibentuk dengan kata-kata, melaporkan pandangan informan secara terperinci, dan disusun secara ilmiah. ${ }^{17}$

Penelitian inimenggunakan wacana sebagai metode analisisnya. Bentuk wacana yang digunakan adalah konsep yang dikembangkan oleh Jager dan Maier.Dalam konsep analisis wacana Jager dan Maier memiliki 6 tahapan analisis, yaitu membuat sinopsis cerita atau ringkasan narasi cerita, menentukan tokoh (tokoh utama) dan relasi antar tokoh, menyeleksi percakapan yang representatif atau praktik diskursif, menjelaskan bentuk-bentuk tindakan atau praktik non diskursif, meterialisasi objek, dan teoretisasi atas tema isi iklan.

${ }^{15}$ Rusman Latief, Yusiatie Utud, Siaran Televisi Non Drama, Kreatif, Produksi, Public Relations, dan Iklan (Jakarta : Prenadamedia Group, 2015), 218.

${ }^{16} \mathrm{Ibid}, 120$.

${ }^{17}$ Hamid Pratilima, Metode Penelitian Kualitatif, (Bandung: Alfabet, 2013), 3. 
Dalam pandangan kritis, media diasumsikan sebagai sebuah entitas kepentingan yang penuh dengan prasangka, retorika, dan propaganda. Menurut Newman, penelitian kritis pertama kali melihat realitas dan hubungan sosial berlangsung dalam suasana timpang. ${ }^{18}$

\section{Hasil dan Pembahasan}

\section{a. Sinopsis Iklan}

Dalam iklan ini dimulai dengan suatu kondisi di pagi hari yang cerah dimana seorang pemuda yang bernama Ahmad sedang mencuci motornyasebelum mengantarkan bapaknya mengambil uang pensiun. Ahmad mencuci motornya sambil berkeluh kesah karena merasa motonya sudah jelek dan tidak kekinian sehingga memohon kepada bapaknya agar membelikan motor yang baru.

Mendengar keluh kesah dan permohonan dari Ahmad, ternyata bapaknya memiliki jalan pikiran lain sehingga tidak mengabulkan permintaan Ahmad. Si bapak memiliki pemikiran bahwa motornya masih bagus dan menyarankan kepada Ahmad saat perjalanan menuju tempat pengambilan uang pensiun sambil berboncengan agar lebih baik uangnya digunakan untuk beramal karena di akhirat semua orang akan bernanung di bawah sedekahnya. Mendengar nasihat dari bapaknya, Ahmad hanya terdiam dan menunjukkan ekspresi ketidakpuasan.

Pada bulan berikutnya, ketika Ahmad sedang berkumpul bersama temantemannya di rumah, bapaknya menghampirinya dan meminta agar Ahmad mengantarkanya untuk mengambil uang pensiun. Sebagai bentuk ketatan pada orang tua, Ahmad memenuhi ajakan bapaknya untuk mengantarkannya. Namun di dalam hatinya, Ahmad masih memiliki perasaan keluh kesah dan keinginan agar dibelikan motor baru.

Setelah mengambil uang pensiun, Ahmad mengantarkan ayahnya ke suatu tempat. Karena tidak ikut masuk ke dalam dan hanya di tempat parkiran, Ahmad melihat ayahnya sedang berinteraksi dengan seorang anak kecil dan ibunya yang sama-sama muslimah. Karena hanya melihat dari kejauhan, hal tersebut membuat Ahmad penasaran tentang siapa sosok yang ditemui bapaknya tersebut.

Pada malam harinya ketika makan malam bersama bapak dan ibunya, Ahmad mengungkapkan penasaranya dengan bertanya langsung kepada bapaknya tentang siapa yang ditemui siang tadi. Namun, bapaknya tidak memberikan jawaban yang jelas dan hanya berkata bahwa suatu saat kamu pasti akan mengerti sendiri siapa mereka.

Ahmad masih penasaran dengan siapa sosok yang ditemui bapaknya tersebut dan apa motif bapaknya menemui mereka. Akhirnya Ahmad pegi ke tempat yang membuat dirinya penasaran tersebut dan melihat sebuah rumah bertuliskan "Rumah Belajar Ahmad". Setelah itu Ahmad menemui perempuan

${ }^{18}$ Eriyanto, Analisis Wacana: Pengantar Analisis Teks Media, (Yogyakarta: Lkis, 2006), 
muslimah tersebut dan bercengkerama bersama-sama. Perempuan tersebut bercerita bahwa Rumah Belajar Ahmad dibuat dari hasil tabungan ayahnya. Melalui hasil sedekahnya, anak-anak di kompleks tersebut memiliki kesempatan untuk belajar.

Pada akhir cerita ditampilkan eksplorasi manfaat dari sedekah yang dilakukan ayahnya dengan diiringi suara dari ayah Ahmad dan disertai teks yang menegaskan bahwa di akhirat semua orang akan bernaung dibawah sedekahnya.

1. Menentukan tokoh utama/subjek

Dalam menentukan tokoh utama atau subjek, peneliti menggunakan analisis struktural Greimas, dimana teks dianalisis sesuai dengan kondisi apa adanya, tanpa memikirkan kapan teks tersebut ditulis, siapa pengarangnya, dan dalam konteks apa teks tersebut diproduksi. ${ }^{19}$

Teks dalam iklan ini diungkap melalui bentuk narasi, analisis pengorganisasian para pelaku atau tokoh beserta peran yang dilakukan. ${ }^{20}$ Dalam iklan ini yang menjadi tokoh utama adalah Ahmad dan bapaknya. Dalam pengorganisasian analisis terdiri dari dua poros hubungan, yaitu poros pencarian yang meliputi hubungan subjek dan objek, dan poros komunikasi yang menjelaskan bagaimana pengirim menyampaikan objek kepada penerima. Pada poros hubungan, relasi yang terjadi adalah berupa hubungan keluarga dimana terjadi interaksi antara Ahmad dan bapaknya sebagai tokoh utama.

Adapun tokoh pendukung yang ada dalam iklan ini adalah temanteman Ahmad, Ibunya Ahmad, dan gadis perempuan kecil beserta ibunya yang muslimah. Peran yang dilakukan oleh tokoh pendukung adalah dalam rangka menguatkan narasi tema pada iklan tersebut. Misalnya Perempuan muslimah dan anak kecilnya berperan sebagai orang yang diberi amanat mengelola rumah belajar. Hal tersebut menjadi bukti keteladanandan contoh nyata sedekah yang sangat bermanfaat yang dijadikan pesan dakwah kepada ahmad.

Pada poros komunikasi, subjek menyampaikan pesan-pesan yang merepresentasikan adanya komodifikasi pesan dakwah melalui lisan, karena interaksi dan komunikasi yang terjadi terjalin secara tatap muka. ${ }^{21}$ Dalam hal ini, pesan dakwah disampaikan secara langsung.

\section{Percakapan yang representatif (Praktik diskursif)}

Iklan memiliki konsep menggiring objek ke arah konsensus sehingga tidak terjadi perlawanan atau mengandung unsur pembantahan

\footnotetext{
${ }^{19}$ Haryatmoko, Critical Discourse Analysis (Analisis Wacana Kritis: Landasan Teori, Metodologi, dan Penerapan, (Jakarta: Rajawali Pers, 2017), 118.

${ }^{20} \mathrm{Ibid}$.

${ }^{21}$ Dalam media televisi, representasi tidak hanya menggambarkan sesuatu yang bersifat fisik, tetapi juga untuk mengetahui makna atau nilai yang terkandung dibalik tampilan fisik. Lihat Graeme Burton, Membincangkan Televisi, Sebuah Pengantar Kepada Studi Televisi (Yogyakarta: Jalasutra, 2007), 41.
} 
yang pada tujuan akhirnya agar objek setuju dengan konsep yang ditawarkan produsen iklan tersebut.

Dalam iklan ini tidak terjadi dialog secara detil yang menggambarkan adanya misi promosi produk, tetapi melalui cerita yang dikemas antara subjek dan objek yang merepresentasikan adanya komodifikasi pesan dakwah yang digunakan.

Dalam menentukan pesan dakwah, tentunya perlu diidentifikasi unsur-unsur dakwah yang ada dalam iklan tersebut. Dakwah dimaknai sebagai kegiatan mengajak, menyeru, mendorong manusia sesuai dengan perintah Tuhan, untuk keselamatan dan kebahagiaan mereka di dunia dan akhirat.

Unsur-unsur dakwah terdiri dari dai atau subjek dakwah, mad'u atau objek dakwah, media dakwah, materi dakwah, dan metode dakwah. Dalam proses komunikasi pada iklan ini, yang menjadi subjek dakwah adalah bapaknya Ahmad. Sedangkan objek dakwahnya atau mad'u adalah Ahmad. Media dakwah yang digunakan adalah dengan lisan melalui komunikasi secara langsung. Metode yang digunakan adalah dengan bil bikmah dan manidzah hasanah melalui keteladanan yang diberikan dan disertai dengan menasehati dengan baik.

Adapun pesan dakwah yang disampaikan adalah berupa ajakan atau dorongan agar mengutamakan sedekah, karena sedekah akan menjadi amal yang menanungi manusia ketika di akhirat kelak. Sebagai bentuk representasi adanya komunikasi dakwah digambarkan dengan percakapan sebagai berikut:

Ahmad : Pak, Motor Ahmad sudah jelek nih!

Bapak : Motornya masih bagus, pakai aja dulu. Lebih baik uangnya buat amal di akhirat, semua orang akan bernaung dibawah sedekahnya.

Setelah mengantarkan bapaknya mengambil uang pensiun, ahmad mengantarkan bapaknya menemui seseorang. Karena tidak melihat dari jarak dekat sehingga membuat Ahmad penasaran tentang siapa sosok yang ditemui bapaknya tersebut. Saat bertemu dengan perempuan tersebut, ahmad mendapatkan bukti sedekah yang dilakukan bapaknya dengan adanya rumah belajar serta keterangan dari perempuan muslimah tersebut sebagaimana keterangan berikut:

Perempuan : Ini adalah tabungan bapakmu, karena sedekahnya anak anak disini jadi punya kesempatan belajar.

Pada akhir cerita, Bapaknya Ahmad juga memberikan pesan penegasan dengan mengucapkan "Jangan lupa, di akhirat semua orang akan bernanung dibawah sedekahnya.

\section{b. Bentuk-bentuk Tindakan (Praktik non diskursif)}


Pada tahap ini akan diungkapkan bukti-bukti terkait komodifikasi pesan dakwah dalam iklan melalui beberapa potongan iklan yang representatif. Gambar atau visualisasi dapat mendorong penafsiran pembaca melalui sugesti dan konotasi. ${ }^{22}$

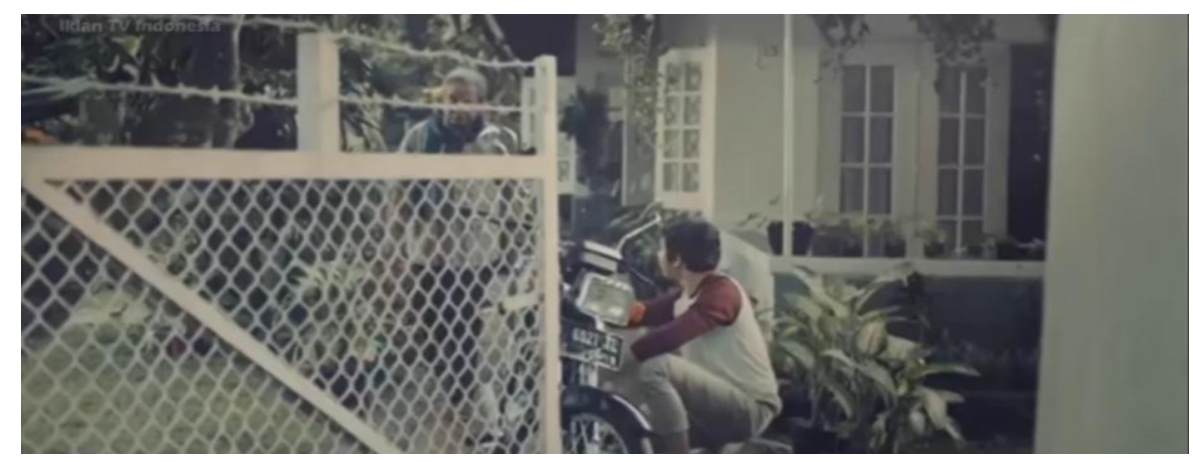

Gambar 1. Ahmad sedang berdialog dengan Bapaknya sambil mencuci motor

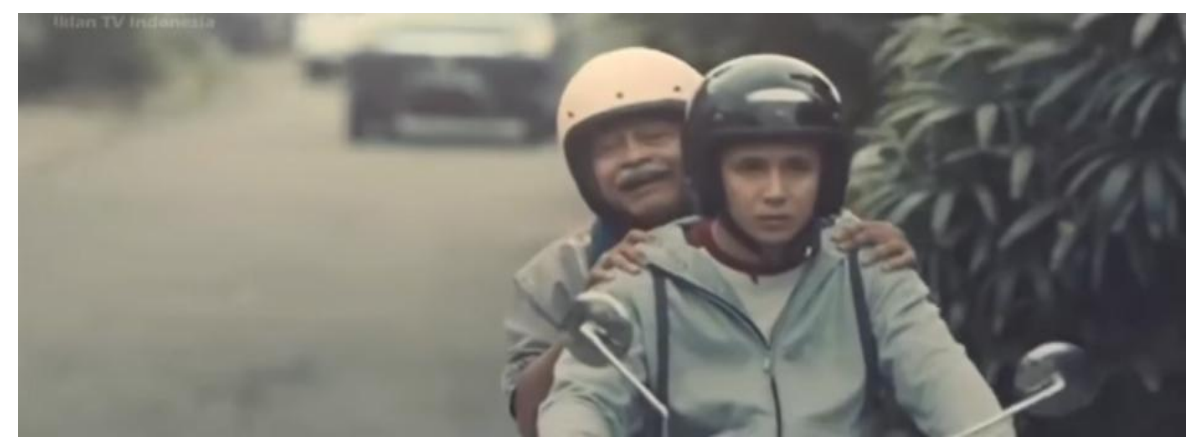

Gambar 2. Ahmad diberi nasihat tentang pentingnya sedekah

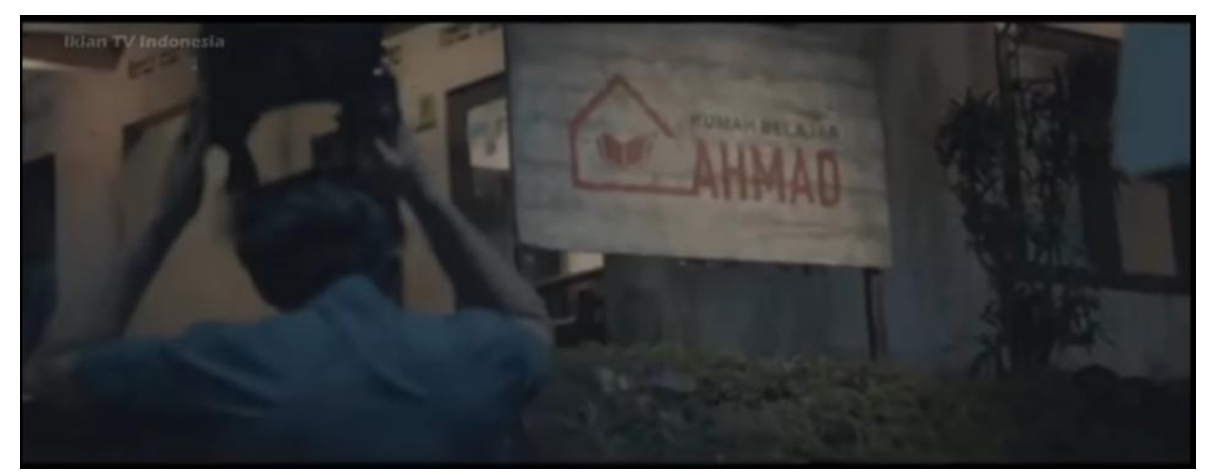

Gambar 3. Rumah Belajar Ahmad sebagai manifestasi sedekah

${ }^{22}$ Haryatmoko, Op.Cit., hlm. 134. 


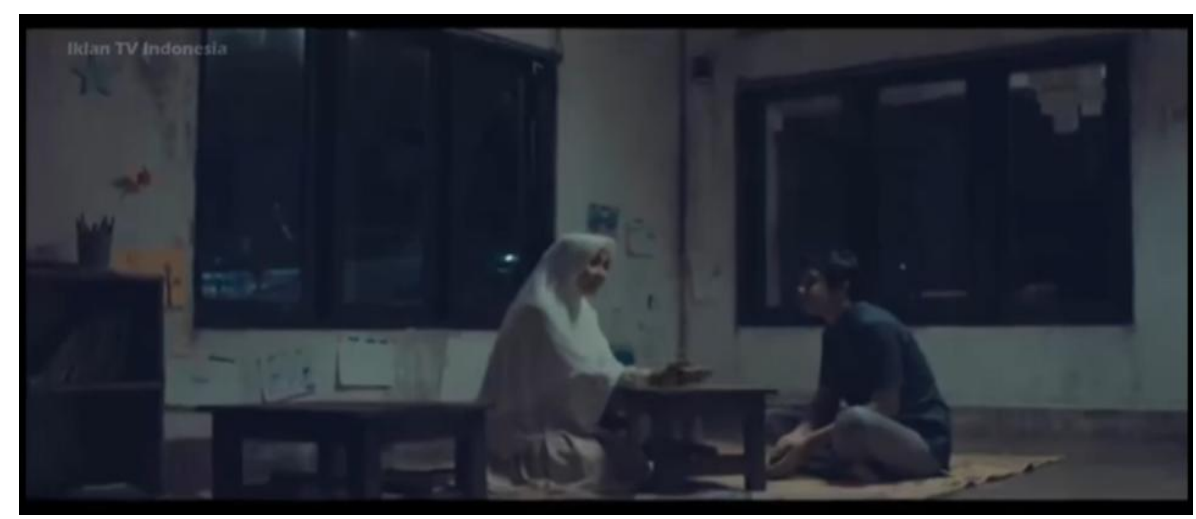

Gambar 4. Perempuan muslimah menjelaskan manfaat dan bukti sedekah.

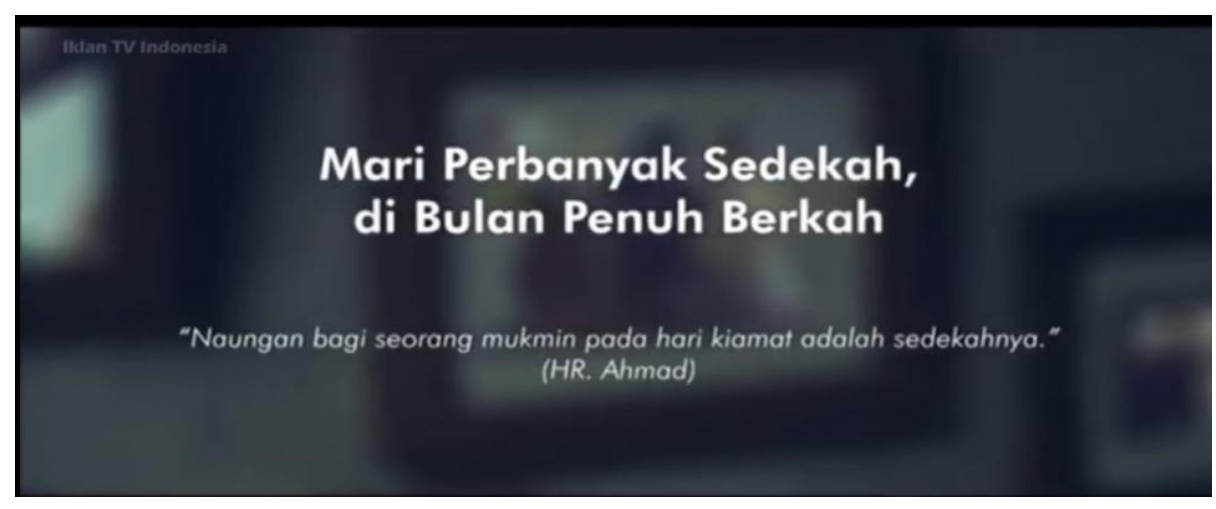

Gambar 5. Teks yang menjelaskan ajakan dan dasar hukum sedekah.

Potongan gambar diatas memberikan ilustrasi yang jelas tentang adanya pesan dakwah yang dijadikan sebagai komoditas pada iklan pertamina ini.

\section{a. Materialisasi Objek}

Dalam iklan ini, terdapat banyak tanda yang ditampilkan sebagai bagian dari materialisasi objek. Iklan ini dimulai dengan menampilkan sosok Ahmad dengan motornya serta membincangkan tentang keinginan dari Ahmad untuk membeli motor baru karena merasa motor yang lama sudah jelek. Objek motor dan topik pembicaraan tentang motor yang ditampilkan pada awal cerita mengindikasikan bahwa Pertamina memiliki pesan yang ingin disampaikan kepada penerima iklan.

Pada umumnya, motor merupakan jenis kendaraan yang memerlukan bahan bakar minyak dalam mobilisasinya. Sedangkan BBM merupakan salah satu dari produk yang dikelola oleh Pertamina selaku 
Badan Usaha Milik Negara (BUMN). Dalam narasi cerita yang mengisahkan bahwa Ahmad tidak diijinkan oleh bapaknya untuk membeli motor baru dengan alasan motornya masih bagus dan menyarankan agar uangnya lebih baik digunakan untuk beramal dikarenakan amal sedekah kelak akan menjadi naungan bagi manusia di akhirat tentu memiliki kepentingan dari korporasi dibelakang maksud tersebut.

Sebagai perusahaan negara yang memiliki fungsi mengelola minyak dan energi serta memastikan agar stok minyak tercukupi tentunya memiliki tugas dan tanggung jawab yang besar terhadap ketersediaan minyak di masyarakat. Dengan semakin bertambahnya jumlah motor dan kendaraan tentunya semakin bertambah pula BBM yang harus disediakan oleh Pertamina. Pesan dakwah yang menjadi komodifikasi pertamina memiliki makna lain agar masyarakat tidak konsumtif dengan membeli motor baru dan agar lebih hemat dalam menggunakan energi.

\section{b. Teoretisasi Tema Isi Iklan.}

Dalam iklan ini, komodifikasi pesan dakwah ditampilkan dengan konsep tema tabungan terbaik. Tabungan merupakan hal yang diasumsikan sebagai sikap dalam rangka berhemat. Sebagaimana penjelasan dalam materialisasi objek bahwa dengan semakin bertambahnya jumlah motor dan kendaraan tentunya semakin bertambah pula BBM yang harus disediakan oleh Pertamina.

Pesan dakwah dikomodifikasi menjadi narasi bahwa amal sedekah akan menjadi naungan manusia ketika di akhirat. Pesan dakwah tersebut disampaikan dalam rangka untuk menyampaikan kepentingan perusahaan agar manusia hemat dalam menggunakan BBM serta tidak konsumtif dengan membeli motor baru.

Dalam iklan tersebut dinarasikan bagaimana seorang anak muda dari keluarga pensiunan pegawai ingin membeli motor baru. Cerita tersebut tentunya dibuat oleh korporasi dari hasil melihat realitas yang terjadi di masyarakat yang sangat konsumtif dalam membeli motor baru.

Selain itu, pesan tersebut yang mengambil sampel dari keluarga pensiunan pegawai ingin dimanfaatkan oleh kreator iklan dalam rangka memberikan pengetahuan agar terjadi perubahan sikap dan perilaku dari mayarakat, khususnya dari pegawai negeri agar memberikan keteladanan dalam memanfaatkan energi.

Pesan dakwah yang merupakan pesan agama yang mulia dalam rangka mengubah manusia menjadi lebih baik dan mendapatkan kebahagiaan di dunia dan akhirat dapat dimanfaatkan sebagai suatu hal untuk transformasi nilai menjadi nilai tukar yang bersifat pembangunan citra demi kepentingan korporasi.

\section{Kesimpulan}


Berdasarkan hasil analisis melalui analisis wacana kritisS Jagerdan F Maier ditemukan adanya tanda yang berupa gambar percakapan dan teks yang mengidentifikasi terjadinya praktik komodifikasi pesan dakwah pada iklan pertamina versi tabungan terbaik. Peneliti menyimpulkan bahwa pesan dakwah yang merupakan pesan agama yang mulia dalam rangka mengubah manusia menjadi lebih baik dan mendapatkan kebahagiaan di dunia dan akhirat dapat dimanfaatkan sebagai suatu hal untuk transformasi nilai menjadi nilai tukar yang bersifat pembangunan citra demi kepentingan korporasi.

Komodifikasi yang terdapat pada iklan ini adalah komodifikasi konten yang terlihat dari adanya tanda-tanda serta penggambaran cerita iklan tersebut. Pesan dakwah yang dijadikan sebuah komoditas yaitu berkaitan dengan pesan sedekah yang dinarasikan akan menjadi naungan manusia ketika di akhirat. Pesan dakwah dikomodifikasi menjadi narasi bahwa amal sedekah akan menjadi naungan manusia ketika di akhirat. Pesan dakwah tersebut disampaikan dalam rangka untuk menyampaikan kepentingan perusahaan agar manusia hemat dalam menggunakan BBM serta tidak konsumtif dengan membeli motor baru.

\section{Daftar Pustaka}

Liliwei, Alo. 1992, Dasar-dasar Komunikasi Periklanan, Bandung: PT. Citra Aditya Bakti.

Keller, dkk., 2009, Manajemen Pemasaran, ed. 13, jil. 2, Jakarta: Erlangga.

Amin, Samsul Munir. 2009, Ilmu Dakwah, Jakarta: Amzah.

Halim, Syaiful. 2013, Postkomodifikasi Media: Analisis Media Televisi Dengan Teori Kritis dan Cultural Studies, Yogyakarta: Jalasutra.

Sukmono, Gita Sukmono, dkk.2013, Ekonomi Politik Media: Sebuah Kajian Kritis, Yogyakarta: LingkarMedia.

Purwodarminto, WJS. 1984, Kamus Umum Bahasa Indonesia, Jakarta: PN. Balai Pustaka.

An Nabiri, Fathul Bahri., 2008, Meniti Jalan Dakwab: Bekal Perjuangan Para Da’i, Jakarta: Amzah.

Bakhtiar, Wardi. 1981, Metode Penelitian Ilmu Dakwah, Jakarta: Logos.

Omar, Toha Yahya. 1984, Imu Dakwah, Jakarta: Wijaya.

Anshari, Hafi. 1993, Pemahaman dan Pengamalan Dakwah, Surabaya: Al Ikhlas.

Badjuri, Adi. 2010, Jurnalistik Televisi, Yogyakarta: Graha Ilmu. 
$150 \mid$ Jurnal Dakwah dan Komunikasi, Vol. 3 No. 2, 2018

Kuswandi, Wawan. 1996, Komunikasi Massa, Sebuah Analisis Media Televisi, Jakarta: PT. Rineka Cipta.

Latief, Rusman., Utud Yusiatie. 2015, Siaran Televisi NonDrama, Kreatif, Produksi, Public Relations, dan Iklan, Jakarta: Prenadamedia Group.

Pratilima, Hamid., 2013, Metode Penelitian Kualitatif, Bandung: Alfabet.

Eriyanto, 2006, Analisis Wacana: Pengantar Analisis Teks Media, Yogyakarta: Lkis.

Haryatmoko,2017, Critical Discourse Analysis (Analisis Wacana Kritis: Landasan Teori, Metodologi, dan Penerapan, Jakarta: Rajawali Pers.

Burton, Graeme., 2007, Membincangkan Televisi, Sebuah Pengantar Kepada Studi Televisi Yogyakarta: Jalasutra.

Faizah., Efendi, Lalu Muchsin., 2006, Psikologi Dakwah, Jakarta: Prenadamedia Group. 